\title{
MINERALOGICAL AND TEXTURAL INFLUENCE ON PHYSICO-MECHANICAL PROPERTIES OF SELECTED GRANITOIDS FROM BESHAM SYNTAXIS, NORTHERN PAKISTAN
}

\author{
Tanveer AHMAD ${ }^{1,2)}$ *, Muhammad RIZWAN ${ }^{2)}$ *, Zeeshan HUSSAIN ${ }^{1)}$, Subhan ULLAH ${ }^{1,2)}$,

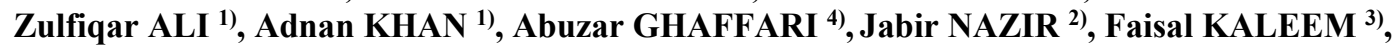 \\ Noor RAHMAN 1), Iftikhar ALI 1), Abdus Saboor KHAN ${ }^{1)}$ and Hamid A. KHAN 1) \\ ${ }^{1)}$ Centre for Earth and Space Sciences University of Swat, Swat-19201, Pakistan \\ 2) National Centre of Excellence in Geology, University of Peshawar, Peshawar-25130, Pakistan \\ ${ }^{3)}$ COMSATS University Islamabad-Abbottabad Campus, Abbottabad-22060, Pakistan \\ 4) FATA University, Darra Adam Khel, FR Kohat, Pakistan
}

*Corresponding author's e-mail: tanveerkhan7773@gmail.com; mrizwan.pk333@gmail.com

\begin{tabular}{l} 
ARTICLE INFO \\
\hline Article history: \\
Received 24 March 2021 \\
Accepted 4 June 2021 \\
Available online 21 July 2021
\end{tabular}

\section{Keywords:}

Besham granitoids

Petrography

Physico-mechanical properties

\section{ABSTRACT}

The Dubair-Shang granitoids are the major intrusive bodies in Besham group and are exposed along the Karakoram Highway in Besham and lower Kohistan districts. A variety of these granitoid rocks have been investigated in terms of their petrographic features and physico-mechanical properties. The studied rocks are classified into four different textural varieties including Dubair mylonitized (DM), Dubair coarse grained (DCG), Shang coarse grained (SCG) and Shang foliated (SF) granitoids based on field observations and petrographic features. Petrographically quartz, potash feldspar, plagioclase and biotite are the essential minerals present in all varieties in varying amount. Beside these hornblende, chlorite, epidote, ore mineral(s) and sphene are also present in the accessory amount. As a part of the present investigation some of the mechanical and physical properties including uniaxial compressive strength (UCS), uniaxial tensile strength (UTS), specific gravity, water absorption, total porosity, and Los Angeles abrasion were also determined. The combined approach of petrographic features with the physico-mechanical investigation revealed that the textural characteristics and mineralogy have a significant influence on the physico-mechanical properties of the studied rocks. It is determined that modal percentage of minerals, degree of alteration, recrystallization, grain size and shape, types of grain boundary contacts have significant effect on characteristics of these granitoids. Based on strength tests studied rocks fall in category of moderately strong to strong. The values of specific gravity, porosity, water absorption and Los Angeles are within the range permissible for their use as constructional materials except SF. Based on physico-mechanical properties and petrographic examination Dubair-Shang granitoids could be used as aggregate for the construction of road, railway tracks, embankment, and canals. Theses rocks could also be used as sills, lentils, and roofing but should not be used for load bearing masonry like bridges, tunnels, buildings, dams etc.

\section{INTRODUCTION}

Granites are most abundantly distributed within the Earth's crust. It commonly occurs in several places in the northern Pakistan. In northern Pakistan, these rocks are distributed, based on tectonic setting and location, i.e., Asian plate, Kohistan zone, IndoPakistan plate (Calkins, 1975; Tahirkheli and Jan, 1979). Dubair-Shang granitoids are few kilometers large bodies present south and north of the Besham town respectively cutting the Besham group rocks and containing xenoliths of Besham gneisses and Lahore granites. These granites are deformed/mylonitic at their margins and massive coarse grained at the core (Baig, 1990).

Granites are used as a dimensional stone and for construction material such that in the designing of foundations for bridges, buildings, dams, highways, railways, canals, spillways, dam abutments, pipelines, penstocks, open pit mines, quarries, etc. It is also used as a design of underground excavations such as tunnels, mines and other underground chambers. However, the use of granitic rock as a construction material depends upon their mechanical and physical properties.

The study of the physical and mechanical properties of rocks and their respective mineralogical and textural characteristics is essential in determining the rocks strength and its capability to use as dimension or building stones. The physico-mechanical properties are largely influenced by their textural characteristics such as grain shape, size, fabric, recrystallization, degree of interlocking, grain contacts, degree of fissuration, alteration and porosity (Irfan, 1996; Tugrul and Zarif, 1999; Gupta and Rao, 
2000; Akesson et al., 2003; Tugrul 2004; Sousa et al., 2005; Tercan and Ozcelik, 2006; Lindqvist et al., 2007; Ceryan et al., 2008a; Fort et al., 2008; Siegesmund and Durrast, 2011; Undul and Tugrul. 2012; Zhang et al., 2012; Sajid and Arif, 2014; Sajid et al., 2016; Sousa, 2017). Rock strength may also be influenced by mineralogical composition and its characteristics and their susceptibility to alteration (Gupta and Rao, 2001; Lan et al., 2003; Gurocak and Kilic, 2005; Haskins, 2006; Woo et al., 2006; Tiryaki and Dikmen., 2006; Karaca and Onargan, 2008; Basu et al., 2012).

Previous work on Intrusive Shang and Dubair granitoids were performed by different authors (e.g., Fletcher et al., 1986; Williams, 1989; La Fortune et al., 1992; DiPietro and Isachsen, 2001; T. Ahmad et al., 2020) but the details regarding physico-mechanical properties and its relationship to petrographic characteristics of the Dubair-Shang granitoids are mostly lacking. The purpose of the present study is to evaluate the detailed physico-mechanical properties of these granitoids and to establish pertinent relationship between the petrographic characteristics and physico-mechanical properties. The conclusion from the present study will be drawn from the geological, petrographic and physico-mechanical details. The resulting conclusion may also be used to determine suitability of these rocks to be use for different engineering purposes. This research also demonstrates that the physico-mechanical property of a rock is strongly influenced by the mineralogical and textural characteristics.

\section{GEOLOGICAL SETTING}

Northern Pakistan is divided into three Petrotectonic domains that are separated from each other by sutures zones. From north to south these domains are, Karakoram microplate, Kohistan Island Arc (KIA), and Indian Plate (Searle et al., 1992, 1999). The Karakoram terrain in northern Pakistan is geologically equivalent to the Qiantang terrain of central Tibet. Kohistan Ladakh Island Arc is bounded between Karakoram terrain to the north along Main Karakoram Thrust (MKT) and Indian Plate to the south along the Main Mantle thrust (MMT) or Indian suture Zone (ISZ) (DiPietro and Pogue, 2004; Searle, 2011; Fig. 1A).

Besham syntaxis is widely regarded as anticlinal flexure which is bounded to the north by Main Mantle Thrust to the west by Swat block and to the east by Hazara block (Baig, 1990; DiPietro et al., 1999; DiPietro and Isachsen, 2001). To the south the Besham syntaxis is separated from low grade metamorphosed to unmetamorphosed sedimentary rocks by thrust faults (Baig, 1990). The Besham syntaxis is traversed by several steeply dipping faults including the Besham fault, Chakessar fault, Farid Ghari fault, Pazang fault, Mamdinsar fault, Pirsar fault and Saker garh fault zone (Baig, 1990). The major deformation and metamorphism in the Besham syntaxis is attributed to the Himalayan Orogeny (Fletcher et al., 1986; La Fortune, 1988).
Besham sequence acts as a tectonic window where the Archean to Proterozoic age crystalline basement rocks of the Indian Plate are exposed due to rapid uplift and subsequent erosion along the Indus gorge (Tahirkheli, 1979). The basement rocks of Besham and Nanga Parbat area are believed to be contemporary as both contain Archean or early Proterozoic protolith and early Proterozoic granitic and amphibolitic rocks (Kazmi and Jan, 1997). The rocks of the Besham area are divided into three different lithological units which include i) The Besham group ii) The Karora group and iii) Intrusive rocks.

The name Besham group was first introduced by Tahirkheli (1979). This group includes a mixture of granitic gneisses, biotitic rich ortho-gneisses, para-gneisses, meta-psammites, blue quartz pegmatites, mylonite, amphibolites, marble and undeformed micro-granites (Fletcher et al., 1986; Williams, 1989).

The Karora Group is pelites rich meta-sedimentary sequence which unconformably rests on the Besham group (La Fortune, 1988). The unconformity between Besham and Karora Group was first recognized by Jan and Tahirkheli (1969). According to Williams (1989), the Karora group consists of basal conglomerate which rests on an angular unconformity and followed by psammitic pelite, graphitic pelite, calc-pelite and lastly marble. A few microgranites have intruded the metasediments of Karora group in late stage of Himalayan deformation (Williams, 1989).

The Besham group is intruded by various episodes of basic dikes and sills (now amphibolites) and granitic rocks (Baig, 1990). The intrusive rocks which intruded the Besham group include: i) Mafic dikes and sills ii) Darwazasar granitic gneisses iii) Lahore sodic granite iv) Shang and Dubair granite and v) Muscovite, tourmaline bearing sodic granite. Mafic dykes are in the form of concordant layers and lenses usually less than $2 \mathrm{~m}$ thick, but some may range up to $50 \mathrm{~m}$ (La Fortune, 1988). These rocks are tholeiitic and display geochemical affinity of island arc which have been metamorphosed to amphibolites (La Fortune, 1988). The Lahore sodic granite intruded the Besham group which shows the Lahore granite is younger than the Besham group. Shang and Dubair granitoid rocks are foliated containing xenoliths of Lahore granite and Besham group. Hence the Dubair granitoid is evidently younger than the former two (Baig, 1990). These granites are deformed/mylonitic at their margins and less deformed coarse grained at the core. All the varieties of granites in this study lie immediately south of the MMT.

\section{METHODOLOGY}

Fresh bulk samples were collected from different textural varieties for detailed petrographic studies and physico-mechanical interpretation. All the samples were free from any kind of discontinuities. Geographic coordinates of collected bulk samples were recorded. Various important field features were photographed 


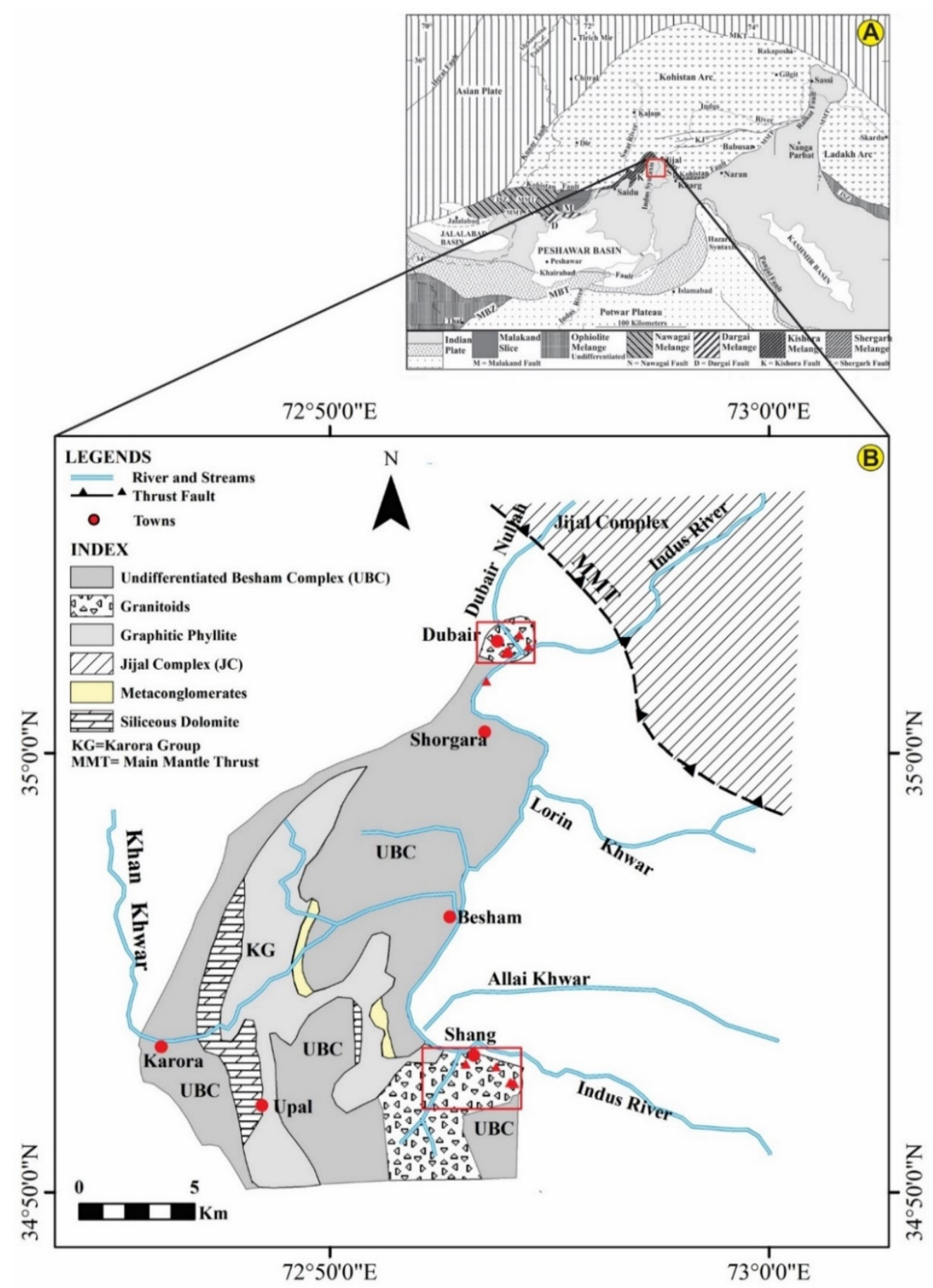

Fig. 1 (A) Regional geological map of northern Pakistan (after DiPietro and Pogue, 2004). The rectangular box shows location of the study area, B) Geological map of the Besham area, northern Pakistan (after La Fortune,1992). The red rectangle encloses the study areas which in turn encloses the sample locations.

and noted (Fig. 2). Five cores from each variety were extracted from bulk sample by core cutting machine to obtain their strength values i.e., Uniaxial Compressive Strength (UCS) and Uniaxial Tensile Strength (UTS) according to (ASTM) specification. All physical and mechanical tests were performed at material testing lab of GEE 3 consultant Rawalakot, Azad Kashmir Pakistan. From each core, slabs were obtained. From these slabs thin sections were prepared at the rock cutting laboratory of National Centre of Excellence in Geology (NCEG), University of Peshawar. Thin sections were studied in the petrography laboratory at Center for Earth and Space Sciences University of Swat (CESS, UOS).

In order to determine physico-mechanical characteristics of Dubair-Shang granitoids representative bulk samples of four different textural varieties were collected from fresh outcrops. Dubair- 

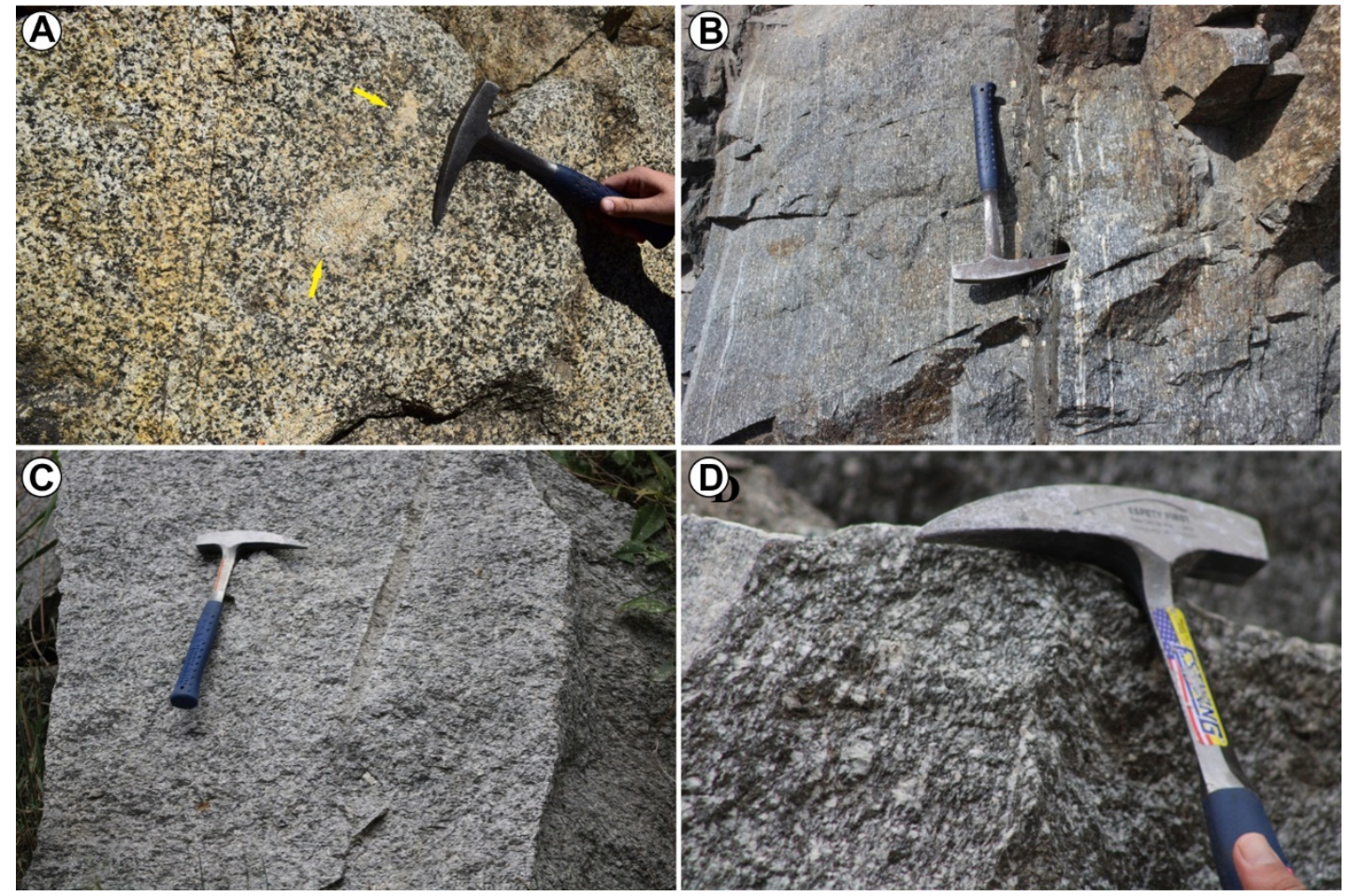

Fig. 2 Field photographs showing A) Dubair coarse grained (DCG) hosting felsic xenolith. White felsic minerals (quartz and feldspar) and mafic (dominantly biotite) can be observed, B) Dubair Mylonitized (DM) granite present along the margin of Dubair plutons. Broken quartz, feldspar grain and alignment of mineral can be seen, C) Shang Coarse grained granites SCG of Shang Valley, D) Shang Foliated (SF) granite (Hammer for scale $=32 \mathrm{~cm}$ in length)

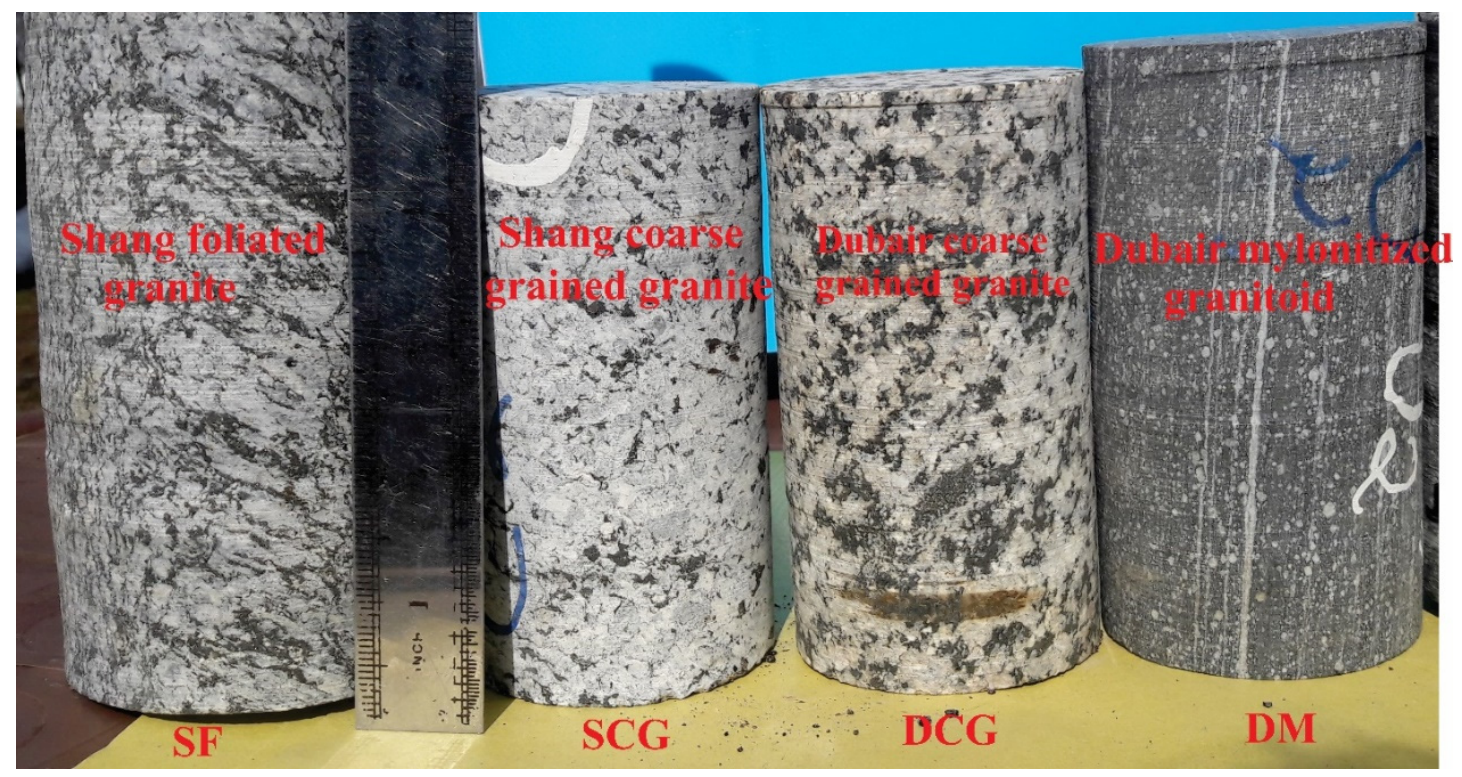

Fig. 3 Photograph showing core samples of the different textural varieties of the studied granitoids.

Shang granitoids of four different textural varieties include Dubair coarse-grained (DCG), Dubair mylonitized (DM), Shang coarse grained (SCG), Shang foliated (SF) granitoid were selected for study. The sample were cored with the help of core drilling machine (Fig. 3). Four cylindrical core samples were obtained from each textural variety and later on these core samples were cut according to the ASTM specifications (ASTM-D2938), in order to determine the mechanical properties like Unconfined Compressive strength (UCS), unconfined tensile strength (UTS). Core samples with $60 \mathrm{~mm}$ diameter were used and a length-to diameter ratio of 2:1 was maintained during UCS testing. For obtaining tensile strength the simple and indirect Brazilian test method UTS (ASTM-D3976) were used using disc-shaped 
Table 1 Showing modal compositions of the different varieties of studied granitoids.

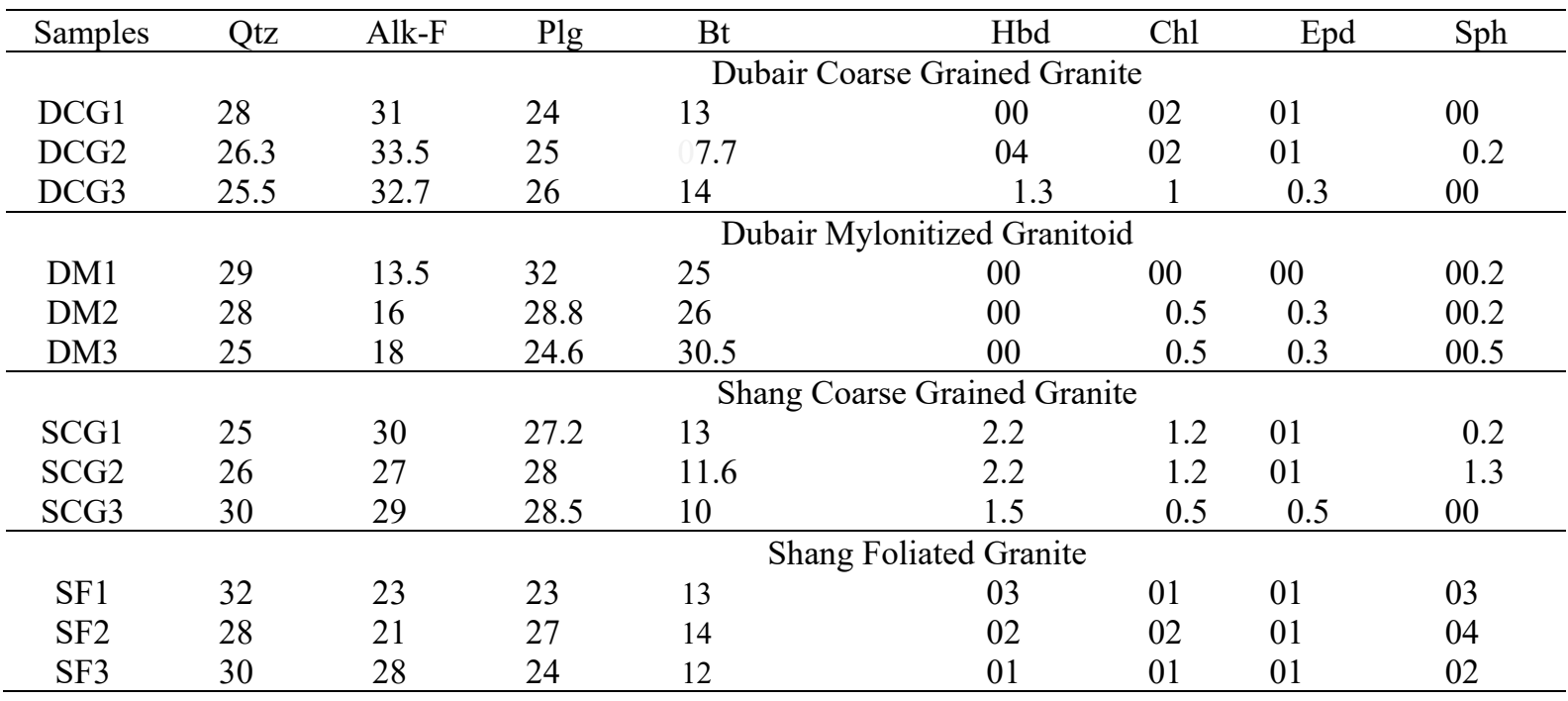

samples with a thickness-to-diameter ratio of 1:2. Physical properties like specific gravity, porosity, and water absorption were determined employing water saturation (ISRM, 2007) method. Los Angeles Abrasion tests were determined in laboratory by Los Angeles abrasion machine.

\section{PETROGRAPHY}

The modal mineralogy and textural relationships within a rock is well described with the help of petrographic studies. The texture, composition and modal mineralogy of minerals present in a rock are responsible for all the physical and mechanical properties of that rock. These properties of rock along with other geological factors, controls and maintaining the engineering properties of the rock. Thin sections were studied in detail under the petrographic microscope to evaluate different textural parameters i.e., grain shape, size, grain contacts and its modal composition. Most of the studied samples were predominantly granitic (only two of the samples from DM variety deviate to the field of granodiorite) in terms of their modal mineralogical composition determined through visual estimates (Table 1; Fig. 4; Le Maitre, 2002). Detailed examination leads to their distinction into four different textural varieties i.e. (DM, DCG, SCG, SF). Detail petrographic accounts of Dubair-Shang granitoid are presented below. A summary of petrographic details is given in the Table 1. The petrographic details are presented in the following paragraph.

\subsection{DUBAIR MYLONITIZED (DM) GRANITOID Hand specimen}

It is the less common rock type present at the margins of the Dubair plutons. The marginal part of the Dubair pluton displays a relatively high temperature mylonitic fabric as demonstrated by the occurrence of recrystallized fine sized felsic minerals, aligned mafic mineral and/or development of preferred orientation (Fig. 2C). This variety is fine grained, xenomorphic, mylonitized and display foliation. Mylonitization is characterized by grain size reduction, recrystallization, broken grains and development of foliated fabric. In Hand Specimen broken plagioclase grains can be identified easily displaying augen structure which is wrapped around by biotite (Fig. 2C).

\section{Microscopic Features}

It is largely composed of quartz, plagioclase, biotite and potash feldspar. Ore minerals, sphene and epidote occur as accessory minerals while sericite and epidote occur as secondary alteration products of plagioclase feldspar. Mylonitized Dubair granite display ultra-mylonitic texture in which plagioclase phenocryst are surrounded by fine sized quartz ribbon and biotite producing a flow pattern Trachytic texture.

Quartz is the most abundant mineral in this variety. It is fine grain in size anhedral in shape having sutured boundaries. Due to stresses quartz grain are shattered into fine masses and are preferably oriented forming a ribbon structure (Figs. 5A, B). Plagioclase grains are subhedral in shape occur as porphyroclast and display diagnostic lamellar twining (Figs. 5A-D). Micro phenocrysts of plagioclase have aligned themselves due to flow displaying Trachytic texture (Figs. 5A, B). Some of the plagioclase grains also show slipping along brittle fault plane which demonstrate the effect of stresses on these rocks (Fig. 5C). Biotite is abundantly present in this variety. It is commonly brown to dark brown in color and mostly occupy a ground mass. It occurs as preferably oriented flakes thus imparting foliation to the host rocks (Figs. 5A-D). Some of the biotite grains are altered along the margin to chlorite by phenomena called chloritization. 


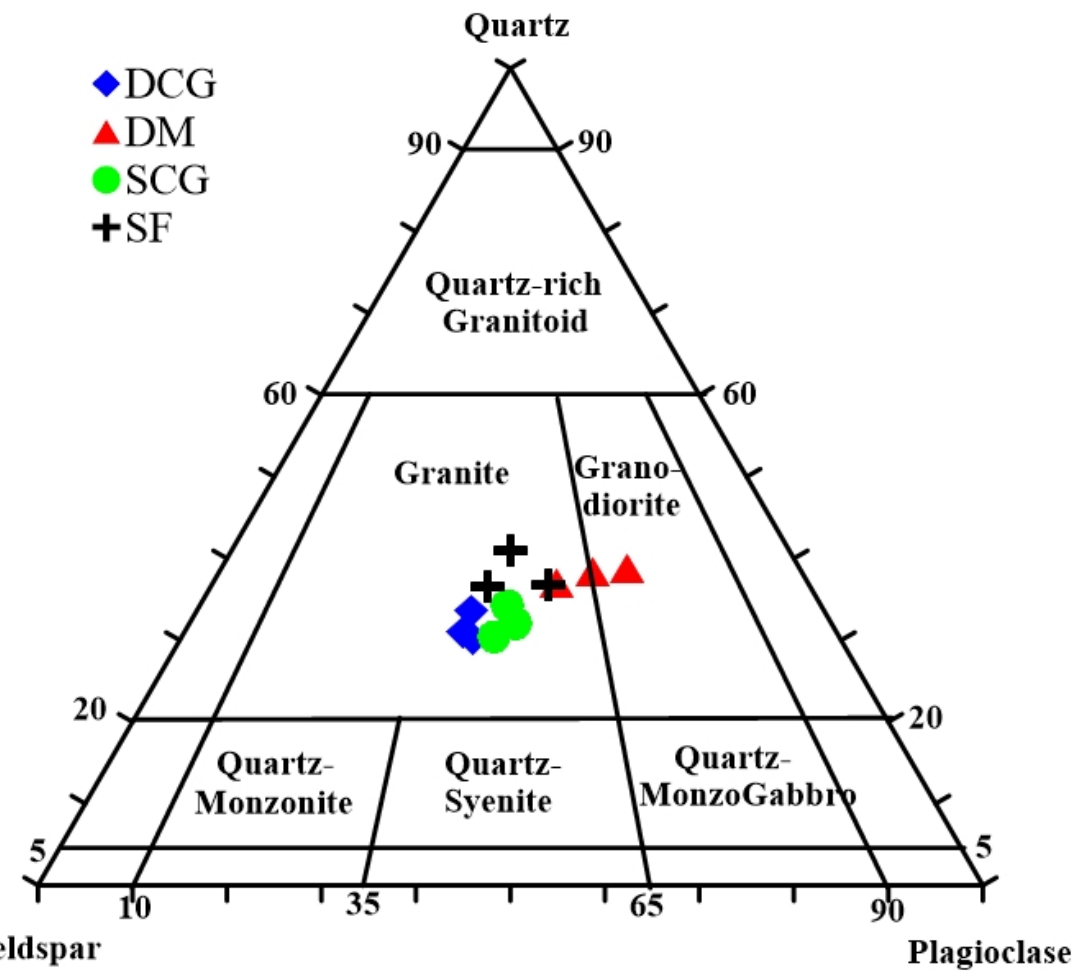

Alkali Feldspar

Plagioclase

Fig. 4 QAP Triangular diagram for the studied granitoids (after Le Maitre, 2002).

$\mathrm{K}$-feldspar of orthoclase variety is mostly present as fine sized grained along with quartz as ground mass however some of them are present as micro phenocryst displaying micro-perthitic texture (Fig. 5D). Epidote is present as a secondary product associated with the altered plagioclase. Ore mineral are present as an inclusion in plagioclase and biotite grains. Sphene is present as accessory mineral mostly associated with biotite.

\subsection{DUBAIR COARSE GRAINED (DCG) GRANITE Hand Specimen Features}

It is common rock type present along the core of Dubair pluton. It is phaneritic, sub inequigranular, sub porphyritic, whitish grey in color, medium to coarse grained slightly mylonitized consist of broken or fragmented grains. At places, they host xenoliths of felsic rocks (Fig. 2A). In hand specimen, grains like feldspar, biotite, amphibole and quartz are easily identifiable. The potash feldspar and plagioclase are present in the form of large phenocryst, subhedral in shape and mostly broken. The matrix is dominantly occupied by shattered and recrystallized biotite and hornblende. Biotite and hornblende are abundant mafic mineral present in these rocks and can be noticed easily in hand specimen (Fig. 2A).

\section{Microscopic Features}

Petrographically this granite is inequigranular, micro-porphyritic, hypidiomorphic to allotriomorphic and dominantly composed of potash feldspar, plagioclase, quartz and biotite, accessory minerals such as hornblende, chlorite, sphene and ore mineral(s) are also present in this variety.

Potash feldspar is the most abundant mineral in this variety. It occurs in the form of subhedral phenocryst displaying microperthetic texture. In most of the potash feldspar pull apart structure are developed due to which fractures are developed which are later filled with quartz or feldspar (Fig. 5E). The plagioclase grains are mostly fresh, well developed and twinned however, some plagioclase grains are partly altered to sericite and epidote due to alteration (Figs. 5 F, G, J). The plagioclase grains are affected by deformational stress as evident from the presence of features such as pull apart crystals, bent structure, kink folding and deformed twins. (Fig. 5F). Quartz is fine in sized and anhedral in shape having sutured boundaries due to grain boundary migration (Figs. 5G-I). They are present as shattered finer mass resulting from brittle deformation of large grain however, some large old relict grains are also present (Figs. 5G, H). Those which are larger strained quartz display wavy or patchy extinction (Fig. 5G). Some of the recrystallized sub grains of quartz are interlocked between large, strained grains (megacryst) of quartz, plagioclase, alkali feldspar forming a ribbon structure (Fig. 5G). Biotite is most abundant mafic mineral in this variety. It is brownish in color subhedral to anhedral and tabular in shape (Fig. 5J). Some of the biotite are altered along the margins to greenish chlorite mineral probably due to chloritization while some are altered to amphibole. Hornblende is second abundant mafic mineral having modal proportion 
Fig. 5
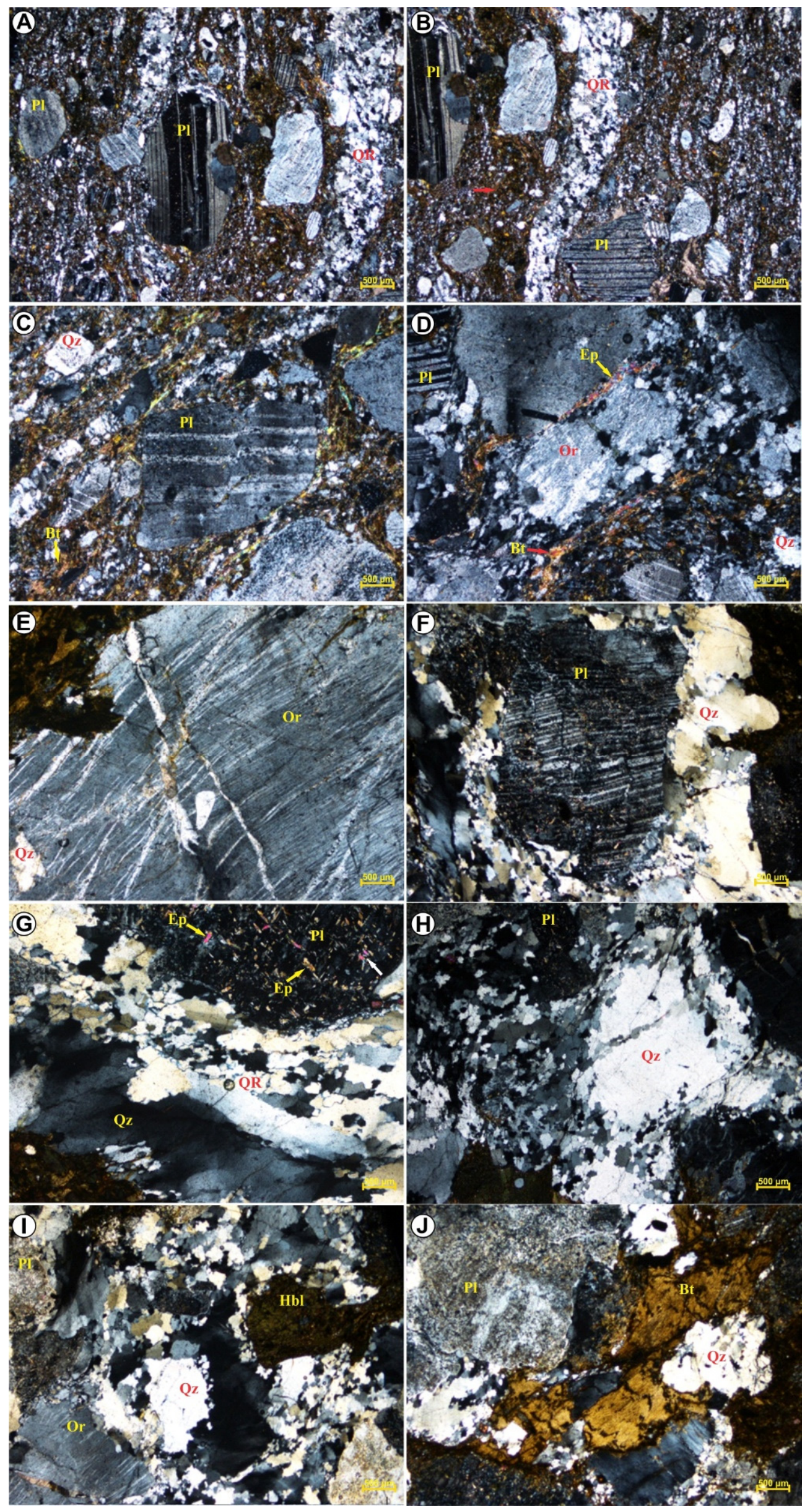
Fig. 6
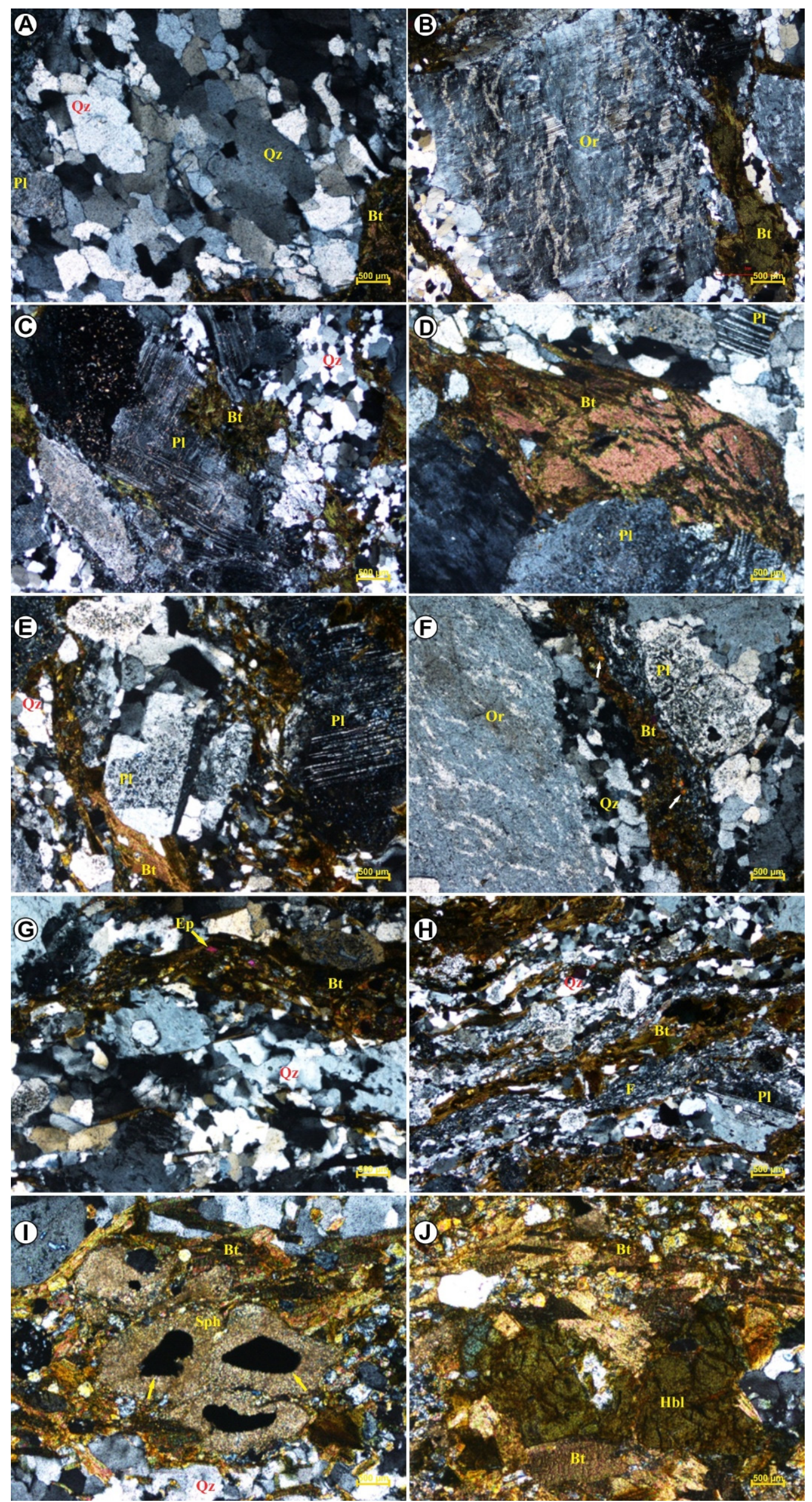
Fig. 5 Photomicrographs (XPL) showing A) Deformational twinning in plagioclase (Pl) and quartz ribbon (QR). Localized change in orientation of kink bands can be seen by change in extinction position between the center and margin of the crystal, B) Strongly elongated polycrystalline quartz ribbon $(\mathrm{QR})$. Note the plagioclase ( $\mathrm{Pl}$ ) porphyroclast having well developed deformational albite twinning which is surrounded by quartz, feldspar and mica aggregate (red arrow), C) Plagioclase $(\mathrm{Pl})$ porphyroclast having brittle fault plane and quartz $(\mathrm{Qz})$. plagioclase grain slipped predominantly due to intragranular deformation, D) Perthitic texture in orthoclase (Or), biotite (Bt), epidote (Ep) and quartz (Qz). Polysynthetic twinning can also be seen in plagioclase (Pl), E) Orthoclase (Or) grain displaying perthitic texture and quartz (Qz). Microcracks can also be seen which are filled with fine grained quartz or feldspar, F) Intensely deformed pull apart plagioclase $(\mathrm{Pl})$ grain having deformational twins surrounded by shattered and recrystallized quartz (Qz) grains forming mortar texture, G) Relict of old strained quartz $(\mathrm{Qz})$ grain exhibiting undulose extinction flattened by intracrystalline deformation and elongate recrystallized sub grains on the top of strained quartz $(\mathrm{Qz})$. Plagioclase $(\mathrm{Pl})$ grain can also be seen at the top portion which host epidotes (Ep), H) Plagioclase (Pl) relict of quartz (Qz) grain surrounded by new recrystallized quartz grains, I) Hornblende ( $\mathrm{Hbl}$ ) surrounded by fine grained polycrystalline quartz (Qz) formed due to grain boundary migration; Plagioclase (Pl) and perthitic texture in orthoclase (Or) can also be seen, J) Intensely altered plagioclase ( $\mathrm{Pl})$, biotite $(\mathrm{Bt})$ along with intragranular deformed quartz $(\mathrm{Qz})$.

Fig. 6 Photomicrographs (XPL) showing A) Quartz (Qz) having intergrown boundaries due to grain boundary migration exhibiting concertal texture, plagioclase $(\mathrm{Pl})$ and biotite $(\mathrm{Bt}) \mathbf{B})$ Orthoclase (Or) phenocryst showing perthitic texture along with fine-grained recrystallized quartz and biotite $(\mathrm{Bt})$ grains at margin, $\mathrm{C}$ ) plagioclase $(\mathrm{Pl})$ having pericline twining, polycrystalline shattered quartz $(\mathrm{Qz})$, and biotite $(\mathrm{Bt}) \mathrm{D})$ Large lenticular biotite $(\mathrm{Bt})$ mica fish surrounded by quartz (Qz) and plagioclase (Pl), E) Zoned plagioclase $(\mathrm{Pl})$ having altered core and fresh margin surrounded by biotite (Bt) and quartz (Qz), F) Orthoclase (Or) having perthite texture bounded to the right by alternate quartz ribbon (Qz) and biotite $(\mathrm{Bt})$ with enclosed epidotes (white arrows). An altered plagioclase ( $\mathrm{Pl}$ ) can also be seen, G) Quartz (Qz) having irregular sutured grain boundaries along with oriented biotite flakes $(\mathrm{Bt})$ with enclosed epidotes (Ep), H) Alternate quartz $(\mathrm{Qz})$, feldspar $(\mathrm{F})$ and biotite $(\mathrm{Bt})$ mica banding defining foliation to the rock, I) Ore mineral (yellow arrows) probably ilmenite rimmed with sphene (Sph) in the center surrounded by biotite (Bt) and quartz (Qz), J) Bluish green hornblende ( $\mathrm{Hbl})$ grain along with brown biotite $(\mathrm{Bt})$.

ranging from 1 to $4 \mathrm{wt} \%$. It is dark green in color, subhedral in shape and is mostly associated with biotite (Fig. 5I).

\subsection{SHANG COARSE GRAINED (SCG) GRANITE Hand Specimen}

It is the most common rock type in the Shang area. This variety is whitish grey, equigranular, medium to coarse grained and massive. In hand specimen grains like quartz, biotite and plagioclase can be identifiable (Fig. 2C). In hand specimen this rock appears white due to a low mafic content relative to Dubair plutons. Quartz is subhedral to anhedral fine in size and abundantly present. Plagioclase is medium in size and subhedral in shape. Biotite is less abundant compared to other varieties and are occasionally noticeable in hand specimen but can be seen in the thin section. (Fig. 2C).

\section{Microscopic Features}

Petrographically this granite is medium to coarse grained, sub equigranular, hypidiomorphic, and sub-porphyritic in texture. It is mostly composed of quartz, potash feldspar (orthoclase), plagioclase and less commonly biotite, sphene and accessory amount of epidote, chlorite and ore minerals are also present. This variety is relatively less altered compared to other varieties.

Quartz is the most abundant mineral present in this variety. It is anhedral in shape having sutured boundary thus displaying consertal texture (Fig. 6A). Most of the quartz grains show undulatory or patchy extinction (Fig. 6A). It also occurs as an inclusion within plagioclase and biotite. Potash-feldspar is the second abundant mineral after quartz in this variety.
Potash feldspar is euhedral to subhedral in shape and occurs as a megacryst surrounded by fine grained quartz and biotite. Potash feldspar (Orthoclase) are relatively fresh and exhibiting a microperthetic texture (Fig. 6B). Plagioclase is the third abundant mineral present in this variety. It is euhedral to subhedral in shape and are present as a phenocryst as well ground mass. Plagioclase grains display diagnostic polysynthetic lamellar and pericline twining (Fig. 6C). Most of the plagioclase grains present in this variety are fresh unaltered however some altered sericitized and saussuritized plagioclase grains are also observed (Figs. 6C, D). Biotite is light brown to dark brown in color, tabular in shape and are present in minor amount relative to other varieties (Fig. 6D). It occurs as a coarse grained as well as fine grained ground mass.

\subsection{SHANG FOLIATED (SF) GRANITE \\ Hand specimen}

It is less common rock type present along the margin of Shang plutons. This variety is fine grained, allotriomorphic, foliated and marked by discontinuous layers of aligned biotite alternating with those dominated by felsic minerals, e.g., quartz, plagioclase and potash feldspar (Fig. 2D). In hand specimen this rock appears dark due to its fine-grained texture and abundant mafic minerals. Plagioclase and potash feldspar are present in the form of broken or fragmented megacryst while quartz and biotite occupy ground mass.

\section{Microscopic Features}

Petrographically plagioclase, potash feldspar and quartz are most abundantly present in this variety. Biotite is also present in appreciable amount. 
Table 2 Showing the physico-mechanical properties of the investigated rock samples.

\begin{tabular}{|c|c|c|c|c|c|c|}
\hline Samples & UCS (Mpa) & $\begin{array}{l}\text { UTS } \\
\text { (Mpa) }\end{array}$ & Specific Gravity & $\begin{array}{c}\text { Water Absorption } \\
(\%)\end{array}$ & Porosity (\%) & Los-Angeles \\
\hline \multicolumn{7}{|c|}{ Dubair Coarse Grained Granite } \\
\hline DCG1 & 66.26 & 4.57 & 2.681 & 0.29 & 0.77 & 17.5 \\
\hline DCG2 & 65.3 & 4.32 & 2.682 & 0.33 & 0.88 & 20 \\
\hline DCG3 & 62.95 & 4.21 & 2.667 & 0.4 & 1.05 & 21 \\
\hline \multicolumn{7}{|c|}{ Dubair Mylonitized Granitoid } \\
\hline DM1 & 72.29 & 5.14 & 2.757 & 0.12 & 0.32 & 20.2 \\
\hline DM2 & 67.33 & 5 & 2.752 & 0.14 & 0.39 & 22.5 \\
\hline DM3 & 62.03 & 4.93 & 2.756 & 0.2 & 0.52 & 26.3 \\
\hline \multicolumn{7}{|c|}{ Shang Coarse Grained Granite } \\
\hline SCG1 & 56.52 & 4.55 & 2.756 & 0.48 & 1.3 & 24.5 \\
\hline SCG2 & 54.12 & 4.04 & 2.722 & 0.53 & 1.47 & 22.3 \\
\hline SCG3 & 60.41 & 4.63 & 2.756 & 0.34 & 0.93 & 21.5 \\
\hline \multicolumn{7}{|c|}{ Shang Foliated Granite } \\
\hline SF1 & 45.93 & 3.68 & 2.722 & 0.38 & 0.92 & 23.3 \\
\hline SF2 & 36.8 & 2.23 & 2.724 & 0.54 & 1.4 & 25.3 \\
\hline SF3 & 41.76 & 3.34 & 2.721 & 0.49 & 1.32 & 24 \\
\hline
\end{tabular}

Hornblende, chlorite, epidote, sphene, amphibole and ore minerals are present as accessory minerals.

Plagioclase is an abundant mineral present in this variety. It is euhedral to subhedral in shape and shows diagnostic lamellar twinning (Fig. 6E). Most of the plagioclase are altered by weathering phenomena's including sericitization and saussuritization (Figs. 6E, F). Some plagioclase hosts secondary epidote and sericite probably formed due to secondary alteration (Fig. 6E). Plagioclase with altered core and fresh margins are also observed in some of the thin sections which probably represent normal zoning in the original plagioclase grain (Fig. 6E). Some of the plagioclase grains are altered so intensely that its internal features are completely obscured. K-feldspar are subhedral in shape and occur as megacryst, surrounded by fine grained quartz. These grains have experienced exsolution phenomenon due to which they display microperthetic texture (Fig. 6F). Quartz is relatively less in abundance in this variety. Most of the quartz grains are shattered to fine masses and lie in parallelism with biotite forming ribbon structure (Fig. 6H). They have sutured boundary with each other thus displaying intergrowth texture due to grain boundary migration (Fig. 6G). Biotite is most abundant mafic mineral in this rock. It shows light brown to strong brown color. It exhibits brown to reddish brown color. It mostly occurs in the form of flakes displaying preferred orientation and thus imparting foliation and gneissosity to the rock (Fig. 6G). Hornblende occurs as subhedral to anhedral, strongly pleochroic grains (Fig. 6J). Its modal abundance is relative less than biotite but is mostly associated with it. Ore mineral(s) probably ilmenite rimmed with titanite are present and associated mostly along with biotite. (Figs. 6I, J). Epidotes are present as aggregate within fine biotite grains (Fig. 6G).

\section{PHYSICO-MECHANICAL PROPERTIES}

The mechanical and physical properties of the studied granitoids were examined which include uniaxial compressive strength (UCS), uniaxial tensile strength (UTS), Los Angeles abrasion (LA), specific gravity, porosity, and water absorption. The corresponding results are reported in Table 2. Overall, Strength properties of DM present slightly higher values followed by DC, SC and SF, respectively. The strength values (UCS, UTS) of three varieties i.e. (DM, DCG, SCG) are high enough to group them in strong category while strength values of SF variety fall them in moderately strong category (Table 3 ). Employing the methods and calculations the water absorption, porosity, specific gravity and Los Angeles abrasion values were also determined. Among all varieties, porosity and water absorption values of SF present slightly higher values while DM presents lower values. While the other two varieties i.e., SCG, DCG show varying values of porosity and water absorption. LA values (23.3-25.3) are higher for SF followed by DM, SCG and DCG respectively (Table 2). All the specific gravity values of the studied samples are $>2.55$ (Table 2).

\section{CORRELATION OF PETROGRAPHIC OBSERVATIONS WITH THE PHYSICO- MECHANICAL PROPERTIES}

In order to determine the reliance of the mineralogical and textural features on the physicomechanical properties of studied granitoids a simple regression analyses were performed to determine coefficient of determination $\left(\mathrm{R}^{2}\right)$, and pertinent correlation were obtained between petrographic characteristics and physico-mechanical properties. To understand the relationship between quartzfeldspar( $(\mathrm{Q} / \mathrm{F})$ ratio and strength values, the $\mathrm{Q} / \mathrm{F}$ values for all samples are plotted against the corresponding 
Table 3 Grades of unconfined compressive strength (Geological Society Engineering Group Working Party 1977; Commission of Engineering Geological Mapping of the IAEG 1979; ISRM Commission on the Classification of Rocks and Rock Masses 1981).

\begin{tabular}{cccccc}
\hline \multicolumn{2}{c}{ Geological Society } & \multicolumn{2}{c}{ IAEG } & \multicolumn{2}{c}{ ISRM } \\
\hline Description & UCS (MPa) & Description & UCS (MPa) & Description & UCS (MPa) \\
\hline Very weak & $<1.25$ & Weak & $<15$ & Very low & $<6$ \\
Weak & $1.25-5.00$ & Moderately weak & $15-50$ & Low & $6-10$ \\
Moderately weak & $5.00-15.50$ & Strong & $50-120$ & Moderate & $20-60$ \\
Moderately strong & $12.50-50$ & Very strong & $120-130$ & High & $60-200$ \\
Strong & $50-100$ & Extremely Strong & Over 230 & Very high & Over 200 \\
Very strong & $100-200$ & & & & \\
Extremely strong & Over 200 & & & & \\
\hline
\end{tabular}

UCS and UTS values. The strong to moderately positive relation exists in resulting plots between these parameters (Figs. 7A, B). This agrees with results obtained by Gunsallus and Kulhawy (1984), Tugrul and Zarif (1999), and Sajid and Arif (2015). UCS values were also plotted against mica modal percent and for all the sample strength values decreases with increase in mica contents (Figs. 8C, D). Among the physical properties porosity and water absorption values were significantly correlated with strength values (Figs. 8A, B). For all the varieties strength values decreases with increase in porosity and water absorption (Figs. 7C, D). This result agrees with earlier study like Sajid and Arif (2015) for Utla granites. Porosity values are also correlated with quartz to feldspar which shows significantly negative relationship with one another (Fig. 7E). The relation between quartz modal percent and porosity with Los Angeles values are significantly decreases with increasing quartz contents and decreases with increasing porosity (Figs. 8E, F).

\section{DISCUSSION}

The main objective of our study is to carryout petrographic examination, and to assess physicomechanical characteristics of the Dubair-Shang granitoids. The resulting data are used to establish pertinent petrographic relation with physicomechanical property in order to find out the influence of texture and mineralogical composition of the specified rocks to its physico-mechanical characteristics and to find out suitability of these rocks for different engineering purpose. Details about the different methods applied and results obtained from these studies are presented earlier. These results are briefly discussed in the following paragraphs.

As mentioned earlier, the strength values of different varieties of granitoids varies drastically. Dubair mylonitized granitoid (DM) is fine grained, mylonitized, allotriomorphic and dominantly composed of quartz, plagioclase, potash feldspar and biotite with minor amount of sericite and epidote. Quartz ribbon structure, trachytic texture, recrystallisation, mortar texture are common microstructural features associated with this variety. The Dubair mylonitized (DM) granitoid have high strength values than the other varieties. The high strength values of the (DM) is due to low water absorption, porosity and Los Angeles abrasion and high specific gravity values (Table 2; Fig. 9). Higher strength values of DM may also be attributed to its fine grained allotriomorphic texture and recrystallised quartz grains. It is generally found that a rock having finer grain are stronger than the coarse grain rock (Tugrul and Zarif, 1999; Bell, 2007). Rocks having allotriomorphic texture where geometry of grains shape and boundary are more irregular increases the strength of the material, this may be due to occurrence of sub-grains at the grain boundaries (Lindqvist et al., 2007). The strength and resistance to mechanical disintegration increases from an idiomorphic texture to allotriomorphic texture (Akesson et al., 2003). Beside these this variety contains appreciable amount of fine-grained recrystallised quartz averaging $27.3 \%$ Table. 1. As quartz are less susceptible to alteration has little or no cleavage and fills the fissures and spaces between the other constituents, its abundance can result in higher strength (Tugrul and Zarif, 1999). Strength of rock decreases due to the increase in volume of voids. Appreciable mechanical effect can be produced due to small change in volume of voids (ISRM, 1981). Moreover, this variety contain large amount of flaky minerals (averaging $27 \%$ ) but these minerals have not adversely affected strength of the rock. The adverse effect of mica may be compensated by other properties i.e., fine-grained allotriomorphic texture, degree of interlocking, low values of porosity and water absorption and presence of appreciable amount of quartz.

Dubair coarse grained (DCG) granitoid and Shang coarse grained (SCG) granitoid are relatively less deformed, idiomorphic to hypidiomorphic, microporphyritic and dominantly composed of quartz, potash feldspar, plagioclase with accessory amount of epidote, chlorite and ore minerals. DCG and SCG have relatively lesser strength values compared to DM which may be due to its coarse grained idiomorphic to hypidiomorphic texture, relatively high waterabsorption values. Idiomorphic texture in which the shape and boundary of the grains is largely regular and defined by straight surfaces enhances the development of discontinuities where cracks can propagate 

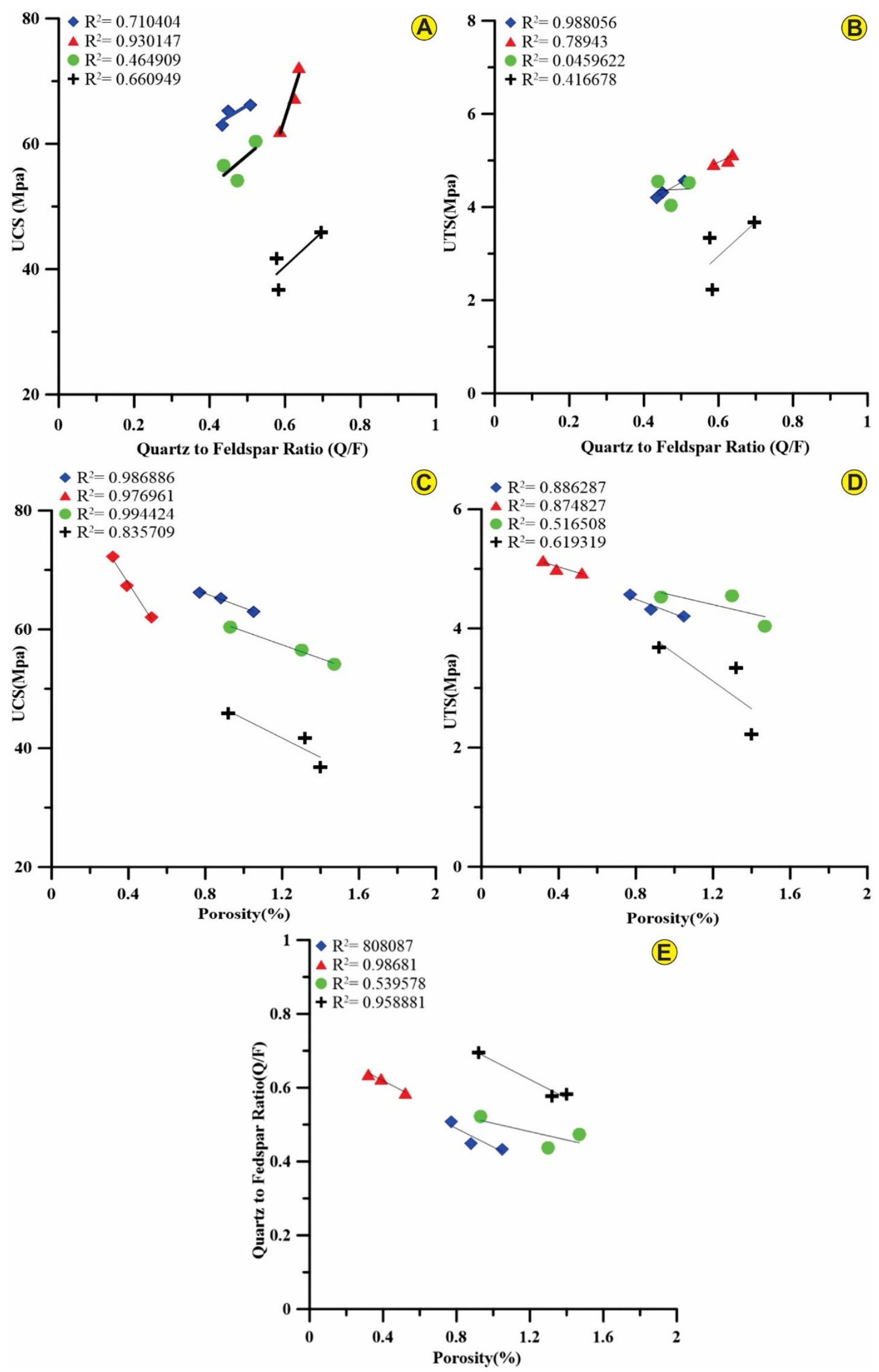

Fig. 7 Showing (A, B) relationship of UCS and UTS with quartz to feldspar (Q/F) ratio, $(C, D, E)$ relation of porosity with UCS, UTS and quartz to feldspar $(\mathrm{Q} / \mathrm{F})$ ratio. 

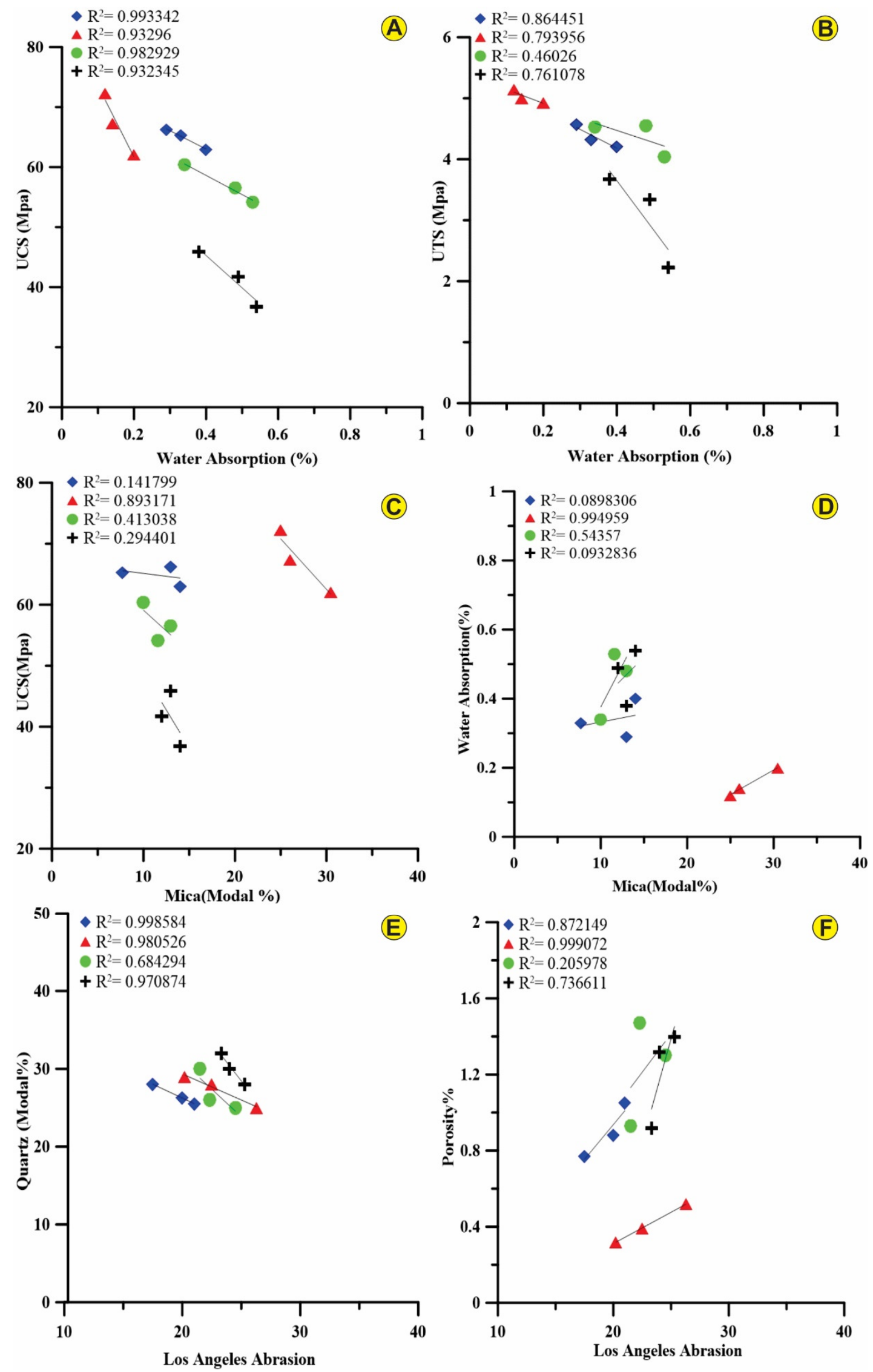

Fig. 8 Showing (A, B) relationship of water absorption with UCS and UTS, (C, D) relationship of mica (modal \%) with UCS and water absorption, (E, F) relationship of Los Angeles Abrasion with Quartz (modal \%) and Porosity \%. 


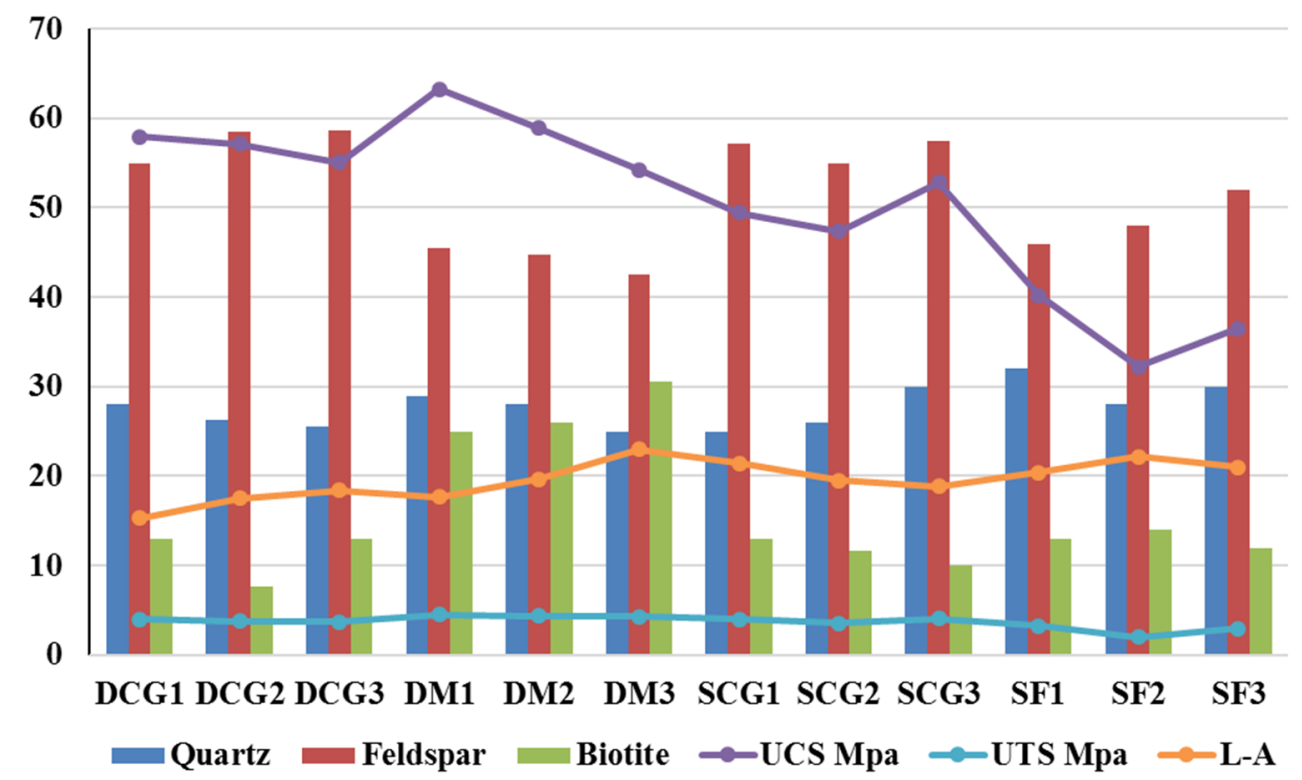

Fig. 9 Bar chart showing the relationship among the percentage of minerals, the uniaxial compressive strength (UCS), uniaxial tensile strength (UTS) and Los Angeles abrasion.

(Akesson et al., 2003; Lindqvist et al., 2007). SCG variety show low strength values compared to DCG despite having high modal percentage of quartz (25 to $30 \%$ ) and lesser amount of biotite and amphibole. The lower strength values of this variety compared to DCG may be attributed to relatively coarse-grained idiomorphic texture and high porosity and water absorption values.

Shang foliated (SF) granitoid is foliated, fined grained and marked by broken grains and development of foliation fabric. This variety is dominantly composed of quartz, potash feldspar, plagioclase with minor amount of hornblende, epidote and ore minerals. Weathering phenomena's like sericitization, saussuritization, chloritization along with microstructural features like kinking, biotite alignment, pull apart grains, shattered quartz grains, and intergrowth texture are commonly associated with this variety. SF variety shows relatively low values of strength despite having the overall greater concentration of quartz (average $=30 \%$ in Table 1 ) compared to all varieties. The decrease in the strength of the fined grained SF granitoid is due to orientation of abundant flaky (mica) minerals and relative greater presence of cleaved, twinned, and intensely altered feldspar grains. The abundance of mineral which are more susceptible to alteration like feldspar, mica and amphibole have deleterious effect on strength values (Lindqvist et al., 2007). The lower strength of SF resulting from the corresponding higher degree of alteration is consistent with previous work described by Coggan et al. (2013). Another reason that SF granitoid shows lowest strength values relative to the other varieties because the preferred alignment of micaceous minerals imparts foliation to the rocks. Due to this foliation planes (which act as large discontinuities) cracks can initiate and propagate easily (Lindqvist et al., 2007). Beside these SF has relatively high porosity, water absorption and LA values probably due to its foliated texture and high degree of alteration.

In order to evaluate the suitability of studied rock samples for their use as construction material, the strength values are compared with International specification (Table 3). According to these grades, the UCS values of three of the varieties i.e., DM, DCG and SCG are within the range permissible for their use as construction material for specific engineering projects. Specific gravity of the investigated samples is greater than the range permissible for their use as construction material. The rocks having specific gravity $\geq 2.55$ are considered suitable for heavy construction and engineering properties (Blyth and De Freitas, 1974). Los Angeles (LA) abrasion values for SF variety is higher compared to other varieties. Increase in loss results into the decrease in strength and the rocks which are more porous will have more loss and less strength (Kilic and Teymen, 2008).

\section{CONCLUSIONS}

1. The studied Dubair-Shang granitoids are broadly classified in to four different categories, which include Dubair mylonitized (DM) granitoid, Dubair coarse grained (DCG) granite, Shang coarse grained (SCG) granite and Shang foliated (SF) granite.

2. All varieties are essentially composed of quartz, potash feldspar, plagioclase and biotite in varying amount, beside these studied rocks also composed of minor amounts of epidote, amphibole, sphene and ore mineral(s).

3. Textural and mineralogical composition strongly influence the mechanical and physical properties of all varieties. 
4. Quartz to feldspar ratio and mica contents are the important mineralogical parameters which effect the physico-mechanical characteristics of studied rocks. Strength values increases with increasing quartz to feldspar ratio and decrease with increasing mica content.

5. Porosity and water absorption values decreases with increasing quartz to feldspar ratio and increases with mica content while Los Angeles abrasion values decrease with increase in quartz modal percent and increases with increase in porosity and degree of alteration.

6. Textural parameters i.e., grain size, shape, grain boundary contacts and degree of interlocking also have strong influence on physico-mechanical properties of studied granitoids.

7. Fine grained Dubair mylonitized granite has highest strength values this may be due to abundant anhedral and recrystallized quartz grains occupying irregular spaces between the other grains, while Shang foliated granite show lesser values among all varieties which may be due to intense deformation, high porosity and water absorption values and presence of abundant altered, cleaved and twinned feldspar minerals.

8. Based on international standards strength values of Dubair mylonitized (DM) granites, Dubair coarse grained (DCG) granites and Shang coarse grained (SCG) granites fall in strong while Shang foliated (SF) fall in moderately strong category.

9. Strength, porosity, water absorption, Los Angeles and specific gravity values suggest that all varieties except SF are within the range permissible for their use in different constructions projects i.e., as aggregate for roads, railway track, canals, drainages and embankments. These rocks can also be recommended for its use as sills, lentils, and roofing. However, they cannot be recommended for use in the construction of largescale engineering structures such as tunnels, bridges, buildings, and dams.

\section{ACKNOWLEDGEMENTS}

We are thankful to the geotechnical and petrography laboratory facilities provided by the National Centre of Excellence in Geology (NCEG), University of Peshawar and Centre for Earth and Space Sciences (CESS), University of Swat, respectively. We are also thankful to Dr. Muhammad Sajid (Assistant Professor, Department of Geology, University of Peshawar) for critical review of first draft which improved the manuscript a lot. This research is self-funded and hence did not receive any specific grant from funding agencies in the public, or commercial sectors.

\section{REFERENCES}

Ahmad, T., Arif, M., Qasim, M. and Sajid, M.: 2021, Petrology of granitoids from Indus syntaxis, northern Pakistan: Implications for PaleoProterozoic A-type magmatism in north-western Indian plate. Geochemistry, 81, 1, 125693.

DOI: $10.1016 /$ j.chemer.2020.125693

Åkesson, U., Stigh, J., Lindqvist, J.E. and Göransson, M.: 2003, The influence of foliation on the fragility of granitic rocks, image analysis and quantitative microscopy. Eng. Geol., 68, 3-4, 275-288. DOI: 10.1016/S0013-7952(02)00233-8

Arif, M., Mulk, A., Mehmood, M.T., and Shah, S.: 1999, Petrography and mechanical properties of the Mansehra granite, Hazara, Pakistan. Geol. Bull. Univ. Peshawar, 32, 41-49.

Baig, M.S.: 1990, Structure and geochronology of PreHimalayan and Himalayan orogenic events in the northwest Himalayan, Pakistan with special reference to the Besham area. Ph.D Thesis, Oregon State University, Corvallis, $300 \mathrm{pp}$.

Basu, A., Ghosh, N. and Das, M.: 2012, Categorizing weathering grades of quartzitic materials and assessing Brazilian tensile strength with reference to assigned grades. Int. J. Rock Mech. Min. Sci., 49, 148-155. DOI: 10.1016/j.ijrmms.2011.11.012

Blyth, F.G.H. and De Freitas, M.H.: 1974, A geology for engineers. ELBS and Edward Arnold, London, 514.

Calkins, J.A., Jamiluddin, S., Bhuyan, K. and Hussain, A.: 1981, Geology and mineral resources of the Chitral-Partsan area, Hindu Kush range, northern Pakistan. USGS, Professional paper 716-G. DOI: $10.3133 / p p 716 \mathrm{G}$

Ceryan, S., Tudes, S. and Ceryan, N.: 2008, A new quantitative weathering classification for igneous rocks. Environ. Geol., 55, 6, 1319-1336. DOI: $10.1007 /$ s00254-007 1080-4

Coggan, J.S., Stead, D., Howe, J.H. and Faulks, C.I.: 2013, Mineralogical controls on the engineering behavior of hydrothermally altered granites under uniaxial compression. Eng. Geol., 160, 89-102. DOI: 10.1016/j.enggeo.2013.04.001

Din, F., Rafiq, M. and Mohammad, N.: 1993, Strength properties of various building stones of NWFP Pakistan. Geol. Bull. Univ. Peshawar, 26, 119-126.

DiPietro, J.A. and Pogue, K.R.: 2004, Tectonostratigraphic subdivisions of the Himalaya: A view from the west. Tectonics, 23, 5 . DOI: $10.1029 / 2003$ TC001554

Dwivedi, R.D., Goel, R.K., Prasad, V. and Sinha, A.: 2008, Thermo-mechanical properties of Indian and other granites. Int. J. Rock Mech. Min. Sci., 45, 3, 303-315. DOI: 10.1016/j.jirmms.2007.05.008

Fletcher, C., Leake, R.C. and Haslam, H.W.: 1986, Tectonic setting, mineralogy and chemistry of a metamorphosed stratiform base metal deposit within the Himalayas of Pakistan. J. Geol. Soc., 143, 3, 521-536. DOI: 10.1144/gsjgs.143.3.0521

Fort, R., Fernández-Revuelta, B., Varas, M.J., De Buergo, M.Á. and Taborda-Duarte, M.: 2008, Influence of anisotropy on the durability of Madrid-region cretaceous dolostone exposed to salt crystallization processes. Mater. Construcc. 58, 289-290, 161-178.

DOI: $10.3989 / \mathrm{mc} .2008 . v 58.1289-290.74$ 
Gibson, S.: 2003, Igneous rocks. A classification and glossary of terms. Recommendations of the International Union of Geological Sciences Subcommission on the Systematics of Igneous Rocks. Geol. Mag., 140, 3, 367.

DOI: $10.1017 /$ S0016756803388028

Gunsallus, K.L. and Kulhawy, F.H.: 1984, A comparative evaluation of rock strength measures. Int. J. Rock Mech. Min. Sci. Geomech. Abstr., 21, 5, 233-248. DOI: 10.1016/0148-9062(84)92680-9

Gupta, A.S. and Rao, K.S.: 2000, Weathering effects on the strength and deformational behavior of crystalline rocks under uniaxial compression state. Eng. Geol., 56, 3-4, 257-274.

DOI: 10.1016/S0013-7952(99)00090-3

Gupta, A.S. and Rao, S.K.: 2001, Weathering indices and their applicability for crystalline rocks. Bull. Eng. Geol. Environ., 60, 3, 201-221. DOI: $10.1007 / \mathrm{s} 100640100113$

Haskins, D.: 2006, Chemical and mineralogical weathering indices as applied to a granite saprolite in south africa. 10th IAEG International Congress, Nottingham, United Kingdom.

Hatheway, A.W.: 2009, The complete ISRM suggested methods for rock characterization, testing and monitoring; 1974-2006. Environ. Eng. Geosci., 15, 1, 47-48.

DOI: 10.2113/gseegeosci.15.1.47

Irfan, T.Y.: 1996, Mineralogy, fabric properties and classification of weathered granites in Hong Kong. Q. J. Eng. Geol. Hydrogeol., 29, 1, 535. DOI: 10.1144/GSL.QJEGH.1996.029.P1.02

Jan, M.Q. and Tahirkheli, R.A.: 1969, The geology of the lower part of Indus Kohistan (Swat), west Pakistan. Geol. Bull. Univ. Peshavar, 4, 1-13.

Karaca, Z. and Onargan, T.: 2008, Microfracture of stones under compressive conditions. Inter. J. Rock Mech. Min. Sci., 45, 4, 638-643. DOI: $10.1016 /$ j.ijrmms.2007.09.002

Kılıç, A. and Teymen, A.: 2008, Determination of mechanical properties of rocks using simple methods. Bull. Eng. Geol. Environ., 67, 2, 237244. DOI: $10.1007 / \mathrm{s} 10064-008-0128-3$

LaFortune, J.R.: 1988, Geology and geochemistry of Indian plate rocks south of the Indus suture, Bosham area, Northern Pakistan. Master Thesis, Oregon State University.

Lindqvist, J., Åkesson, U. and Malaga, K.: 2007, Microstructure and functional properties of rock materials. Mater. Charact., 58, 11-12, 1183 1188. DOI: $10.1016 /$ j.matchar.2007.04.012

Lundqvist, S. and Göransson, M.: 2001, Evaluation and interpretation of microscopic parameters vs. mechanical properties of Precambrian rocks from the Stockholm region, Sweden. Proc. Eighth Euroseminar on Microscopy Applied to Building Materials, Athens, 13-20.

Sajid, M. and Arif, M.: 2015, Reliance of physicomechanical properties on petrographic characteristics: Consequences from the study of utla granites, north-west Pakistan. Bull. Eng. Geol. Environ., 74, 4, 1321-1330.

DOI: $10.1007 / \mathrm{s} 10064-014-0690-9$
Searle, M.P., Crawford, M.B. and Rex, A.J.: 1992, Field relations, geochemistry, origin and emplacement of the Baltoro granite, central Karakoram. Earth Environ. Sci. Trans. R. Soc. Edinb., 83, 3, 519-538. DOI: $10.1017 / \mathrm{S} 0263593300005861$

Searle, M.P., Khan, M.A., Fraser, J.E., Gough, S.J. and Jan, M.Q.: 1999, The tectonic evolution of the KohistanKarakoram collision belt along the Karakoram highway transect, north Pakistan. Tectonics, 18, 6, 929-949. DOI: 10.1029/1999TC900042

Siegesmund, S. and Dürrast, H.: 2011, Physical and mechanical properties of rocks. In: Stone in architecture, 97-225. DOI: $10.1007 / 978-3-642-14475-2 \_3$

Sousa, L.M., Río, L.M.S.D., Calleja, L., Argandona, V.D. and Rey, A.R.: 2005, Influence of microfractures and porosity on the physico-mechanical properties and weathering of ornamental granites. Eng. Geol., 77, 12, 153-168. DOI: 10.1016/j.enggeo.2004.10.001

Tahirkheli, R.K.: 1979, Geology of Kohistan and adjoining Eurasian and Indo-Pakistan continents, Pakistan. Geol. Bull. Univ. Peshawar, 11, 1, 1-30.

Tercan, A.E. and Ozcelik, Y.: 2006, Canonical ridge correlation of mechanical and engineering index properties. Int. J. Rock Mech. Min. Sci., 43, 1, 58-65. DOI: $10.1016 /$ j.ijrmms.2005.04.002

Tiryaki, B. and Dikmen, A.C.: 2006, Effects of rock properties on specific cutting energy in linear cutting of sandstones by picks. Rock Mech. Rock Eng., 39, 2, 89-120. DOI: 10.1007/s00603-005-0062-7

Tuğrul, A.: 2004, The effect of weathering on pore geometry and compressive strength of selected rock types from Turkey. Eng. Geol., 75, 3-4, 215-227. DOI: $10.1016 /$ j.enggeo.2004.05.008

Tugrul, A. and Gurnapial, O.: 1997, The effect of chemical weathering on the engineering properties of Eocene basalts in northeastern Turkey. Environ. Eng. Geosci., $3,2,225-234$.

Tuğrul, A. and Zarif, I.H.: 1999, Correlation of mineralogical and textural characteristics with engineering properties of selected granitic rocks from Turkey. Eng. Geol., 51, 4, 303-317. DOI: $10.1016 / \mathrm{S} 0013-7952(98) 00071-4$

Ündül, Ö. and Tuğrul, A.: 2012, The influence of weathering on the engineering properties of dunites. Rock Mech. Rock Eng., 45, 2, 225-239. DOI: $10.1007 / \mathrm{s} 00603-011-0174-1$

Willard, R.J. and McWilliams, J.R.: 1997, Microstructural techniques in the study of physical properties of rock. Int. J. Rock Mech. Min. Sci. Geomech. Abstr., 6, 1, 112. DOI: $10.1016 / 0148-9062(69) 90025-4$

Woo, I., Fleurisson, J.L. and Park, H.J.: 2006, Classification of weathering for granite and granite gneiss in south Korea. Proc. 10th IAEG International Congress, IAEG2006 Paper, 131.

Zhang, L., Ding, X. and Budhu, M.: 2012, A rock expert system for the evaluation of rock properties. Int. J. Rock Mech. Min. Sci., 50, 124-132. DOI: 10.1016/j.ijrmms.2012.01.009 